\title{
Reflection as an Effort for Early Childhood Teachers Development
}

\author{
Lukluk Husnawati ${ }^{1 *}$ and Sugito ${ }^{2}$ \\ 1*Department of Early Childhood Education, Yogyakarta State University, Indonesia \\ ${ }^{2}$ Department of Non-Formal Education, Yogyakarta State University, Indonesia \\ 1*luklukhusnawati1993@gmail.com
}

\begin{abstract}
This paper presents the development of skills of teachers in the education of children of early age do the teaching reflection. Teacher of child in early age $(n=15)$ need to develop competencies themselves in various ways. One of them is through the teaching of reflection to improve the quality of teaching and discuss how the development of skills of teachers of early childhood education can be done in the district of Sleman, Yogyakarta Indonesia. This type of research is qualitative research. Data was obtained through extracting information from educators who talked about the way their head teachers who have expertise in managing learning in class. The analytical method used is content analysis. This article is the process of reflection, the follow-up results of the reflection, and fact to the factor of reflection. The reflection process carried out is the most influential variable in the process of development towards teacher expertise. This research shows that the development of early childhood education teacher skills requires new work methods and steps for educational planning. One attempt is to use teaching reflection to gather the needs for individual growth plans, which will be easier if the reflection is done in a collaborative manner with colleagues. The teacher will naturally feel which areas of learning need to be strengthened the most as a result of teaching reflection. As a result, teachers are continually striving to improve their own learning abilities, which in turn improve student learning outcomes.
\end{abstract}

Keyword: Reflection, Teacher professionalism, Early childhood teachers

\section{Introduction}

In the 1960s, when the theory of behaviourism dominated thought and philosophy of education, this made the teacher-centered paradigm dominant in teacher learning practices and caused teachers to be the only source of learning for students. However, when the theory of humanistic psychology developed in the 1970s accompanied by the birth of publications Bloom in [1], Bruner in [2], Piaget and Cook in [3] and Vygotsky in [4], had shifted the paradigm to student-centered where students were assumed to be students active subjects who can create and find their own validation through their unique experience with the environment. As a professional who has a strong scientific foundation and solid learning practices, teachers are required to be able to follow these paradigm changes because it will have a major impact on learning practices in the classroom.

To be able to follow these changes, the teacher must have teacher professionalism with the development of teacher expertise. Forms of teacher expertise development can be done

Article history:

Received (February 18, 2020), Review Result (March 22, 2020), Accepted (May 28, 2020) 
individually, namely through teacher initiatives to develop themselves, develop scientific competencies, conduct reflections and classroom action research, read scientific journals, expand networks, increase personal library collections, and so on. The development of teacher expertise can also be done institutionally or by initiatives from school principals or related educational authorities, for example through associations in teacher forums such as teacher working groups, children's teacher associations. The purpose of this article is to learn how to support the development of early childhood education teacher skills through reflection activities on teaching in the Ngaglik District, Sleman, Yogyakarta Indonesia. The research questions are:

(1) How teachers of children ages early conduct the reflection process as an effort to support the development of skills?

(2) How teachers of children ages early to follow up the results of reflection that has been done for the development of expertise?

(3) What factors influence early childhood teachers in reflecting on skills development?

The rest of this paper is organized as follow. Section 2 describes the proposed method. Section 3 describes the Results: Reflection as an Effort to Develop Early Childhood Teacher Skills. Finally, Section 4 concludes this work and following by cover.

\section{Proposed method}

This research was conducted in Ngaglik District, Sleman, Yogyakarta, Indonesia. The group that is the subject of the study consisted of teacher education of children aged early to work in kindergarten and have at least a bachelor's degree. This research uses a qualitative approach. The study subjects were asked to fill out a questionnaire and provide information in the form of biographies of teachers of children aged self. In addition, the questionnaire used was to fill in about "The journey of the city towards the development of early childhood teacher skills through the reflection of teaching that has been carried out". In other words, research subjects were asked to share their stories about how they developed their expertise as professional teachers written in essay form. To consider the reliability of qualitative research, the demand for truth and objectivity of research is very important [5].

Research subjects write about their expertise and development in a free form and define the variables associated with expertise in the reflection actions taken. The personal experience of each teacher with the expertise possessed will show the truth with his own. However, it is likely that some common characteristics and consistent commonalities between the research individuals will be discovered later [6]. Questionnaires were sent to all research subjects $(n=33)$ and finally, 15 early childhood education teachers in Ngaglik District participated in the study and wrote their stories (the research subject's response rate was 45, $45 \%$ ). [Table 1] provides an overview of the characteristics of the research subjects. 
Table 1. Characteristic research subjects

\begin{tabular}{|c|c|}
\hline \multicolumn{2}{|c|}{ Gender $(n=15)$} \\
\hline Male & $2(13.3 \%)$ \\
\hline Female & $13(86.7 \%)$ \\
\hline \multicolumn{2}{|c|}{ Age $(n=15)$} \\
\hline $23-27$ years & $5(33.3 \%)$ \\
\hline $28-32$ years & $3(20 \%)$ \\
\hline $33-37$ years & $1(6.7 \%)$ \\
\hline $38-42$ years & $1(6.7 \%)$ \\
\hline 43-47 years & $2(13.3 \%)$ \\
\hline $48-52$ years & $2(13.3 \%)$ \\
\hline $53-57$ years & $1(6.7 \%)$ \\
\hline \multicolumn{2}{|c|}{ Level Education $(n=15)$} \\
\hline Bachelor of early childhood education & $9(60 \%)$ \\
\hline Bachelor of Non-Education in early childhood & $\begin{array}{c}5(33.3 \%) \\
\text { Bachelor of Mathematics Education } 1 \\
\text { person } \\
\text { - Bachelor of Psychology } 2 \text { people } \\
\text { - Bachelor of Communication Studies } 1 \\
\text { person } \\
\text { Bachelor of English Education 1 person }\end{array}$ \\
\hline Postgraduate early childhood education & $1(6.7 \%)$ \\
\hline
\end{tabular}

NB. Percentages presented in this table are based on the percentage of study subjects were regarded as a teacher of children ages early quality.

The analysis used is content analysis and begins by looking for elements of teacher knowledge related to self-development. The analysis is carried out inductively: first by reducing data and then by grouping. The unit of analysis is chosen according to the research objectives and research questions. The first stage of the analysis is carried out with quotations that illustrate the development of expertise gained from the stories written by the research subjects. This data reduction is done by dividing the data into several parts. The second stage of analysis is the grouping of quotations by general nominees [7][8].

\section{Results: Reflection as an effort to develop early childhood teacher skills}

Teachers of children of early age participate in this study describes the development process well, while teachers who can download a single event or experience of others who suffered greatly affects their skills in classroom teaching. Almost every subject of the study $(\mathrm{n}=13,86.7 \%)$ said that their expertise developed while becoming early childhood teachers when carrying out lesson plans in the classroom. Two of the research subjects did not analyze the development of their skills, but just describes the changes in work or the realization of the changes that will be made. As a result, the three variables obtained in the process of reflection to develop towards membership of the teachers, namely: reflection method which includes the activities of reflection as a learning process and measures reflection, the follow-up results of the reflections include personal development, development of students, the school and the environment, as well as factors which influences reflection for the development of early childhood teacher skills. The following is a description of the research variables: 


\subsection{Reflection process}

In the view of early childhood education teachers in this study, new experiences and information about their own professional fields are considered as the most important variables for skills development. Through reflection, the teacher will develop the ability to solve problems. By questioning and changing the way teachers deliver lessons, teachers will find new solutions and become more flexible with classroom teaching. This allows the teacher to take the time to assess and appreciate his own teaching. More than half of the research subjects $(n=9,60 \%)$ said that by reflecting on teaching they had significantly developed their expertise.

Teachers of children aged early reflect the importance of teaching in two ways. First, do most or some reflection activities that include reflection journal, video recording, school committees, collaboration/cooperation between teachers, community teacher learning and action research. Second, step by step reflection is cyclical which consists of finding problems/irregularities, understand the actions/experiences, investigate the problem to understand the causes, find alternatives and make a plan of action, making the action, analyze and evaluate past. Teachers of children aged early insight that spontaneously come together while doing the right reflection of the condition that an intention or desire to be even better. Jamil et al. [9] said the development of expertise can be in the form of formal experiences such as attending workshops and mentoring and can be obtained through informal experience through watching television documentaries related to academic disciplines, reading references, and up to date latest news. The skills development activities undertaken by the teacher will be able to improve the competence of teaching competencies in the classroom and be the subject of up-to-date knowledge and increase creativity in using learning methods that are fun for students.

A teacher is not enough just having experience only to be professional in the learning process in the classroom, but teachers will need to learn how to teach the learners. One way that teacher can do in increasing the roles and responsibilities of their teacher's expertise are by reflecting. Miller et al. [10] explain that self-reflection is a major element of teacher expertise. Reflecting on the practice of teacher expertise, especially learning and teaching is an important factor for the formation of innovation and learning revolution in the classroom [11]. Most teachers will ask how important they are to reflect and what their benefits are when reflecting. Teachers of children aged early in particular feel they have no spare time for reflection. Busyness from morning to evening and so on, this makes teachers struggle with routines that are less supportive for self-development.

The teacher conducts teaching just by everyday experiences. It is precisely here that the reflection is very necessary. In doing teaching every day certainly will not be timeless by irregularities or irregularities in learning. The teacher will wonder how the teacher can solve the irregularities that become big questions in the hope of getting a better solution. When a person cannot enjoy a new experience because it does not have a match between the current experience and the new experience, as John Dewey wrote in the early twentieth century, it is required to discover further information to overcome the mismatch. This process is called reflection. Dewey [12] writes ". . . to reflect, means to look for additional evidence, for new data, which will develop suggestions, and will, as we say, prove it or explain its irregularities and irregularities. "With the teacher who is aware that there are irregularities experienced, the teacher will try to find information to get self-understanding from various sources including through collaboration with fellow teachers or can be done individually. Ryan [13] revealed that there are two basic similarities that are key to reflection, namely (1) making a 
sense of experience in relation to oneself, others and contextual conditions, and (2) rearranging and/or planning future experiences for personal and benefits social. In line with this point of view, Fullana argues that learning as a cyclical process that starts from a problematic action or when someone experiences an unfavourable situation, then tries to understand an action or experience, conduct an investigation to understand the cause, find alternatives and make an action plan, and then make actions, analysis, and evaluation. This cyclical action becomes one of the steps for the teacher to reflect, so that the teacher is able to become a lifelong learner.

\subsection{Follow up on the results of reflection}

Teacher's skill development is always an individual process and is not always bound to work for years [14]. The key to developing teacher expertise is where the teacher has a desire to change to a better direction to develop teaching skills and learning planning. As a result, the topic of this study's research has been working for anything from 3 months to 30 years, which is a significantly different perspective from the analysis's findings. Experience played a role in the process of developing skills, as stated by $(n=13,86.7 \%)$ of the subject of research.

The teachers mentioned that experience level was a variable that increased their expertise and over time the quality of experience increased and had an impact on the development of early childhood education teacher skills. The confidence that results from increased experience can be seen as increased development which also gives courage to rise to new levels of challenges. Besides that, other people in the teacher community can influence the development of skills because of interaction and collaboration.

Teacher skills development is needed to fill the gaps in the professionalism of new teachers and always strive to develop their skills [15]. Nasiri et al. [16] say that the development of teacher expertise is needed so that teachers stay up to date and continue to make changes to learning practices according to the needs of students. The purpose of developing teacher expertise is also explained by Guskey [17] that there are three main development objectives, namely: developing professionalism will bring changes to teacher learning practices in the classroom, can increase teacher confidence and have an impact on improving student learning outcomes. Gebreselassie [18] said that the aim of professional learning activities is to improve practice, increase self-confidence, attitudes and understanding or knowledge that teachers have, therefore teachers will be more creative in facing new challenges and overcome positive changes by continuously updating knowledge and skills teacher. As with the opinion of Monroe in [19] states that the main purpose of professional development should not only focus on improving individual alone, will but also attach great importance to the improvement of schools and the education system. In short, the purpose of teacher skill development will affect changes in teacher performance mainly on teaching practices in the classroom and is expected to have a positive impact directly or indirectly on the school and the learning of students.

Self-reflection activities are activities that provide many benefits in the development of teacher skills [10][11][20][21][22]. The main benefit of this is to help teachers gain a deeper understanding of themselves, the profession and how they can become effective, efficient teachers, and make students successful in learning. In addition, self-reflection can also help teachers to explore the potential that exists in them, fix weaknesses and find the solutions they need for the development of their profession. Therefore, self-reflection was a contributing factor to assist teachers in developing teacher expertise, and the subsequent impact of course will have a positive influence on efficiency in teaching and learning activities in class which 
leads to an increase in the development of learners in accordance with the stages of his age. The teacher's self-reflection in relation to efforts to develop the expertise of his teacher is also in line with other studies in the psychological context that show that self-reflection can have a positive impact on human self-development. This is associated with efforts to develop selfawareness that must be seen as something fun, valuable experience to explore the potential in a person and use it as a basis for taking an action. With this, a teacher does not need to be too deeply absorbed in the sadness or badness of his past and can be more focused on efforts to develop himself. Of course, this gives the benefit is huge for an educator who is of course also very impact on the lives of learners - learners her. If a teacher has and show the positive qualities in him when he was in front of students, it can give positive energy transfer to learners her [20].

With self-reflection, a teacher can learn to activate the process of awareness of selfteaching skills during their teaching and in this way can make contact with students in the learning process properly. Good teaching activities can be marked by the right balance of aspects of teacher awareness and the professionalism demands of a teacher in various matters academic and non - academic. Ideally, teacher professional development programs should also focus on the potential and needs of teachers that begin with a reflection process carried out by a teacher in the development of the teaching profession. This section is very important as a material consideration in designing the process of teacher professional development activities.

Self-reflection has the potential to stimulate one's emotional self-awareness in a better way. This can help to make it more natural to include feelings; emotions, needs, and values in him that will help him become a better self. Restricting beliefs in many educators / teachers do not appear to be such matters that need more attention for researchers in the development of the teaching profession. This can be seen from the relatively few references that discuss specifically the importance of self-reflection for teachers in the development of teacher skills. More specifically, the belief to initiate change that is good for educators / teachers will have an impact on competency improvement needed to deepen the development of teacher expertise. Not only are competencies influenced by people's beliefs, but the belief that they have or can develop competencies to have a greater impact on the development of their teacher's expertise. In the end, paying more attention to self-reflection in the development of their teacher's expertise can help teachers to become more aware of the quality of their students, so that they will be able to guide these children in their learning, and help them mobilize the quality of their students in school and in their future lives. This is important in the process of constructing knowledge, attitudes and skills of both the teacher and the students themselves.

\subsection{Reflection factors}

There are reasons why there are teachers who want to reflect and there are also teachers who are reluctant to do reflection even though reflection is included in the field of competencies that teachers must master. The factors that make teachers reluctant to reflect include:

(1) Don't have free time because reflection takes a long time? Reflection can be done on the spot (Schön: reflection-in-action). The teacher must reflect on the things that happen in the class. Ask yourself about the following: What works? How? Why? What do students stand for? Why? Do learners se fullest understanding the instructions of teachers? If not, why not? Do students fully understand their assignments? If not, why not? 
(2) Reflection is only focused on the teacher, and reflection does not directly affect students. Reflecting and responding to teacher's reflection will directly affect students as the teacher changes and adjusts teaching. The teacher will relearn and reassess the lessons that the teacher has taught, and this will allow students the opportunity to acquire new skills and strengthen learning. Creating an evaluation model will help the teacher know whether the actions that the teacher has taken have the desired effect.

(3) Reflection is a negative process for some teachers. Reflection is a cycle process, which means the teacher grows and adapts. Teachers must plan to utilize their own strengths and coworkers' best practices, which then apply to their own teaching. By engaging in a supportive network, everyone will develop.

(4) Reflection is an individual process, so how do know a person has improved. Reflection is best done when part of the supporting tissue. Teachers can take advantage of coworkers' support by asking them to observe and provide feedback. Teachers can also take advantage of student feedback. Factors supporting the enthusiasm of teachers to reflect such support from principals, their colleagues who is making positive changes for the development of skills and the enhancement of learners and flexible spare time to reflect on teaching.

\section{Conclusion}

Levels in the development of teacher expertise are different. Self- development towards professional teachers is an individual process and each professional needs to find their own developmental path. Because there is a relationship between educational beliefs and practices, teachers of children in the early years should be able to reflect on their work in order to gain expertise. That is why reflection must be made at every level of education of children of early age every day. With the work, the teacher will learn from each other and jointly common problems encountered along the group of teacher. Early childhood teachers need to expand the notion of individual expertise in the field of collaborative expertise and social sharing.

Teachers of children aged early start to work early after graduation will assume that the development of expertise may be it is still difficult to do because they need to explore the experience and wider knowledge. The most sensitive phase of professional development arises about 3-6 years after starting work. Furthermore, armed with information and new skills will have a concrete connection to work and a teacher of young children will be able to do experimental. But for teachers, who have long taught, reflect depth can go to work every day in evaluating educational action. Teachers involved in the process of reflection on strategies for solving practical problems and their daily pedagogical interactions, are able to articulate their professional knowledge and gain a deeper understanding of their theory and practice.

The path to professional development will always be personal and emerge as a mixed process. The process of reflection and the follow-up results of work reflection form the part that is considered and challenged by the need to support the development of expertise. Therefore, it is reasonable to discuss mainly the variables that have the effect of reflection action undertaken, the process of reflection of teachers of children ages early actionable at the community level - that is, the environment of the school, school leaders and co-workers. It's important to pay attention not limited to differences of region al - such as access to skills development are sustainable and support networks, the size of the working community, the distance between the relevant partners to do the job together - but also with the contents of reflection for the development of skills itself so will fulfill the requirements and challenges as 
an early childhood teacher today along with the aspirations of the teacher's personal development.

\section{Cover}

Changes will continue to occur over time, what young children need to do is be able to face challenges and be able to make decisions in the future by always improving themselves and having a good impact on students, schools and the surrounding environment. There is a lack of this that not everyone knows the signs of contradictions that occur in society. Therefore, early childhood teachers are required to be able to reflect on the reality they face, the knowledge they have, and the values that form the basis of every step of their lives in a sustainable manner.

\section{References}

[1] B. S. Bloom, "A response to Slavin's mastery learning reconsidered. Review of educational research," vol.57, no.4, pp.507-8

[2] J. S. Bruner, "Toward a theory of instruction," Harvard University Press, vol.59

[3] J. Piaget and M. Cook, "The origins of intelligence in children," vol.8, no.5, pp.18, New York: International Universities Press

[4] L. Vygotsky, "Interaction between learning and development, readings on the development of children," vol.23, no.3, pp.34-41

[5] T. Zheng, "Research on primary arithmetic fact mastery for elementary school children education in China: A computerized programming model of problem building," International Journal of u - and e-Service, Science and Technology, vol.8, no.7, July, pp.387-396, (2015) DOI: 10.14257/ijunnesst.2015.8.7.39

[6] E. Buchbinder and O. Bareqet-Moshe, "Hope and siege: The experiences of parents whose children were placed in residential care," Residential Treatment for Children and Youth, vol.28, no.2, pp.120-139, (2011)

[7] E.G. Guba and Y. S. Lincoln, "Effective evaluation: Improving the usefulness of evaluation results through responsive and naturalistic approaches," Jossey-Bass

[8] C. -H. Le and S. -H. Jin, and W. -H. Lee, "A study of psychotherapy plan through game graphics focused on the colour preference of children," International Journal of $u$ - and e-Service, Science and Technology, vol.9, no.7, July, pp.287-298, (2016) DOI: 10.14257/ijunnesst.2016.9.7.29

[9] H. Jamil, N. A. Razak, R. Raju, and A. R. Mohamed, "Teacher professional development in Malaysia: Issues and challenges," Africa-Asia University Dialogue for Educational Development Network, pp.85-102, (2007)

[10] J. A. Miller and C. T. Bowman, "Mechanism and modeling of nitrogen chemistry in combustion," Progress in energy and combustion science, vol.15, no.4, pp.287-338

[11] J. J. Loughran, "Developing reflective practice: Learning about teaching and learning through modeling," Bristol: Falmer Press, (2005)

[12] J. Dewey, "How we think," New York: Prometheus Books

[13] R. Mary, "The pedagogical balancing act: Teaching reflection in higher education," Teaching in Higher Education, vol.18, no.2, pp.144-155, (2017) DOI: 10.1080/13562517.2012.694104

[14] H. M. Collins and R. Evans, "The third wave of social studies: Studies of expertise and experience," Social Studies of Science, vol.32, no.2, pp.235-296, (2002)

[15] A. T. Evers, B. I. van der Heijden, K. Kreijns, and M. Vermeulen, "Job demands, job resources, and flexible competence: The mediating role of teachers' professional development at work," Journal of Career Development, vol.43, no.3, pp.227-243, (2016)

[16] Z. Nasiri-Toosi, S. Dashti-Khavidaki, M. Nasiri-Toosi, A. Jafarian, H. Khalili, S. Badri, and S. Sadrai, "Clinical pharmacokinetics of Tacrolimus in Iranian liver transplant recipients," Iranian Journal of Pharmaceutical Research: IJPR, vol.13, no.1, pp.279, (2014) 
[17] T. R. Guskey, "Professional development and teacher change," Teachers and teaching, vol.8, no.3, pp.381391, (2002)

[18] M. Gebreselassie, "Principals 'roles in fostering teachers' continuous professional development: In government secondary schools of Addis Ababa," Ph.D. dissertation, Addis Ababa University, Addis Ababa, Ethiopia, (2015)

[19] C. J. Li, M. C. Monroe, A. Oxarart, and T. Ritchie, "Building teachers' self-efficacy in teaching about climate change through educative curriculum and professional development," Applied Environmental Education and Communication, pp.1-15, (2019)

[20] F. Korthagen and A. Vasalos, "Levels in reflection: Core reflection as a means to enhance professional growth," Teachers and teaching, vol.11, no.1, pp.47-71, (2005)

[21] B. Avalos, "Teacher professional development in teaching and teacher education over ten years," Teaching and teacher education, vol.27, no.1, pp.10-20, (2011)

[22] Mahdum, "Constraints in English speaking: A case study on students of teacher training and education faculty, RIAU university, Indonesia,” International Journal of u - and e-Service, Science and Technology, vol.10, no.4, April pp.197-206, (2017) DOI: 10.14257/ijunnesst.2017.10.4.14 
Reflection as an Effort for Early Childhood Teachers Development

This page is empty by intention. 